\title{
El Dios de Jesús fundamento de la espiritualidad cristiana
}

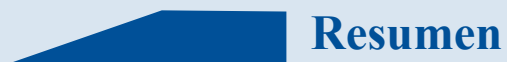

No se puede hablar de espiritualidad cristiana sin remitirnos a Jesús de Nazaret, quien con su práctica comprometida nos comunica esa imagen correcta de Dios para fundar una recta espiritualidad.

No obstante, a largo de la historia se han construido muchas imágenes de Dios que han inspirado diferentes espiritualidades que, al estar alejadas del Dios revelado por Jesús, se hicieron alienantes y destructivas para la vida cristiana. De ahí que tengamos que regresar a Jesús y descubrir a Dios en la imagen del Padre, amoroso y misericordioso para una espiritualidad saludable de apertura y reconocimiento para nosotros mismos y los demás.

Palabras clave: Imágenes de Dios, espiritualidades, espiritualidad cristiana, Jesús.

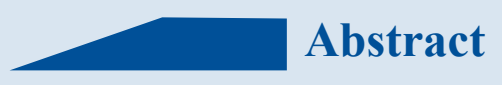

We can not speak of Christian spirituality without referring to Jesus of Nazareth who, with his committed practice, communicates to us that correct image of God in order to found a correct spirituality.

Nevertheless, throughout history many images of God have been constructed, which have inspired different spiritualities that, to be distant from the God revealed by Jesus, became alienating and destructive to Christian life. Hence, we need to return to Jesus and discover God in the image of the loving and merciful Father for a healthy spirituality of openness and recognition for ourselves and others.

Key words: Images of God, spiritualities, Christian spirituality, Jesus.

\section{Introducción}

Hablar de espiritualidad cristiana necesariamente nos remite a Dios como fundamento radical $\mathrm{y}$ último de toda espiritualidad cristiana. Nos relaciona con Dios mismo que es el centro y única referencia absoluta de la experiencia cristiana. El problema se sitúa no en el tipo de espiritualidad que tengamos, sino en la imagen de Dios que está fundando nuestra espiritualidad.
Nuestra tesis fundamental es que no puede haber espiritualidad cristiana que no remita a Dios, pero no cualquier imagen sino sólo aquella que Jesús nos ha comunicado.

De ahí que nos preguntemos ¿en qué consiste una recta espiritualidad cristiana desde la imagen de Dios que Jesús nos ha comunicado?

- Profersor de teología Sistemática y Filosofía. Docente Investigador de la Escuela de Teología. Universidad Politécnica de Nicaragua (UPOLI). Correo: escuelateologia3@upoli.edu.ni / ORCID: https://orcid.org/0000-0001-9610-8611 
Qué imagen de Dios y qué espiritualidad

El teólogo Torres Queiruga (1996) sostiene que la imagen que tenemos de Dios condiciona nuestra visión del mundo. Asimismo, podemos considerar que la imagen de Dios que hayamos asumido por herencia de ciertas tradiciones religiosas así será nuestra espiritualidad.

A toda pregunta por la espiritualidad cristiana en su concreción práctica, le precede la pregunta radical sobre Dios ¿Qué imagen de Dios fundamenta nuestras espiritualidades? De hecho, no hay persona sin espiritualidad. La cuestión es saber qué imagen de Dios es la que nos mueve, nos anima o impulsa nuestra vida.

Al referirnos a la imagen de Dios nos remitimos a los modelos imaginativos icónicos que son aceptados o compartidos tanto por quienes afirman a Dios, como por los que lo rechazan o lo niegan. Dichas imágenes las sacamos de la realidad del mundo que nos rodea (Núñez de Castro, 2010). Así, desde siempre nos hemos esforzado en configurar una imagen de Dios a modo de orientación teórico-práctico, que sea capaz de guiar, pero a su vez de justificar nuestra práctica concreta en la vida. (Arocena, 2014)

La cultura siempre ha sido el marco de referencia tanto de valores como signos que presta imágenes y palabras a la conciencia colectiva en cada momento histórico para todo discurso, incluso el discurso sobre Dios. (Núñez de Castro, 2010)

Esto se debe a que no tenemos acceso directo a Dios, pues la revelación siempre está mediada por la palabra humana, es una revelación oblicua. Esta limitación de nuestro acceso a la revelación ha seguido como efecto una diversidad de imágenes de Dios que no siempre le hacen justicia a Dios, pues hablar bien de Dios resulta imposible, "pues su trascendencia supera por todos los costados las capacidades de la comprensión y la expresión humana". (Torres Queiruga, sf, p.2)

\section{Acercamiento al qué de la espiritualidad}

El tema de la espiritualidad ha sido un tema transversal en el pensamiento teológico, más de alguna reflexión de algún teólogo ha puesto en la mesa de reflexión dicho tema.

En su definición general el concepto de espiritualidad a criterio de Casaldáliga (1993), se ha convertido en una palabra infeliz, desmoralizante por el abuso teórico-práctico con que se ha utilizado.

Observemos dos aspectos fundamentales para comprender la espiritualidad en su sentido general: Primeramente, hay que asumir que toda espiritualidad es de modo general constitutiva en el ser humano, no es algo agregado en nosotros, sino que es expresión concreta en la práctica cotidiana de nuestro propio ser; remite a las motivaciones, sueños, utopías, pasión, es la mística como impulso por la cual vivimos, luchamos y contagiamos a otros. (Casaldáliga, 1993)

Para Galilea (1985), la espiritualidad remite a la mística en tanto que motivación que impregna los proyectos y compromisos de vida, tanto los que consideramos importantes como los cotidianamente oscuros (p.26). 
El teólogo Boff (2012), la comprende como una remitencia a la interioridad y profundidad con que el ser humano mira su realidad. Por su parte Gutiérrez (1975), la define como una totalidad en el sujeto personal y grupal remitido a la totalidad histórica.

En segundo lugar, toda espiritualidad debe comprenderse desde una visión integral, es decir, desde una única realidad individual, social e histórica (Zubiri 1983). Por la cosmovisión dualista y dicotómica de la cultura occidental, hemos entendido el espíritu contrapuesto a la materia, como consecuencia, se ha pensado el mundo dividido en dos planos completos en sí mismos y en oposición: un plano superior de las esencias e ideas, de lo inmutable y eterno en donde se ha colocado a Dios; mientras que en el plano inferior de lo sensible-material, se considera todo lo perecedero, corruptible en donde se ha colocado la vida terrena, corporal e histórica ( Dussel, 1975). De ahí se sigue que lo espiritual es remontado hasta la región a- histórica e inmutable del primer plano (Silva Gotay, 1983) en una total distancia con lo terreno.

Muy al contrario de comprender la espiritualidad como un elevarse al cielo, o trascender lo terreno ha de comprenderse como un penetrar en profundidad nuestra realidad personal. De ahí que para entender integralmente la espiritualidad hemos de empezar a ver lo espiritual y material como dos dimensiones del ser humano en correspondencia, con su autonomía, pero siempre en respectividad (Ellacuría, 2002). Lo espiritual no es una parte de la vida sino de toda la vida que se siente animada por el espíritu. No hay vida humana terrena y vida espiritual, más bien es la vida humana como realidad compleja constituida en una pluralidad de notas. (Zubiri, 1989)

De ahí que para hacer justicia de la espiritualidad desde una visión integral la reflexión teológica se ha de situar desde el horizonte de la cosmovisión semita de la tradición bíblica en donde el espíritu no se opone a la materia, ni es algo que está fuera de la materia, del cuerpo o fuera de la realidad sino algo que está dentro, que inhabita la materia, el cuerpo, la realidad, y les da vida, los hace ser lo que son; los llena de fuerza, los mueve, los impulsa, los lanza al crecimiento y a la creatividad en un ímpetu de libertad. (Dussel, 1975 y Casaldáliga, 1993)

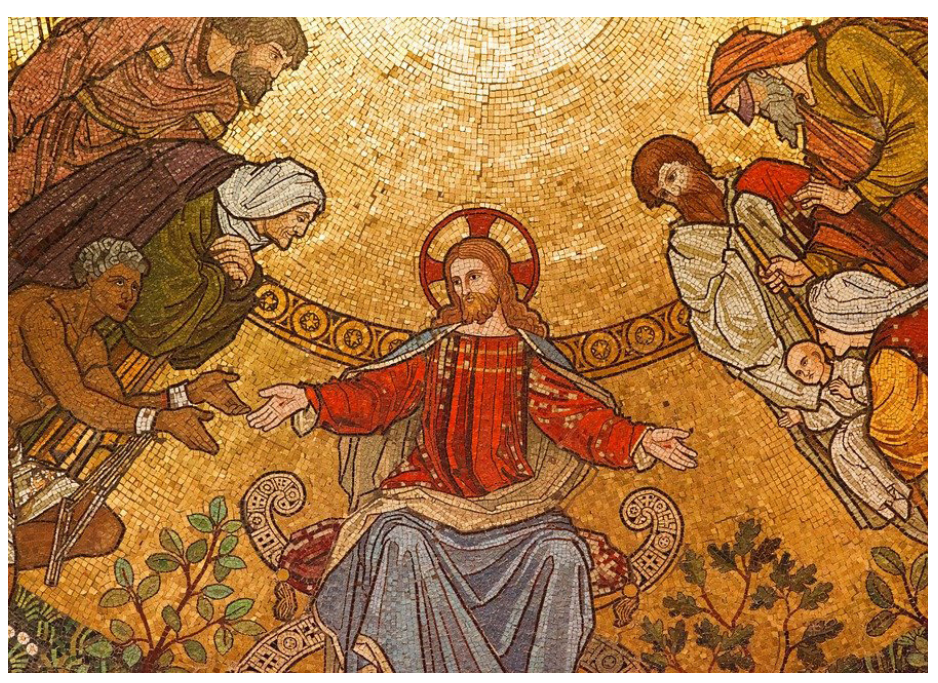

Pixabay.com

La espiritualidad desde el horizonte cristiano

La espiritualidad definida como cristiana se sustenta en su sentido fundante en que está remitida a la persona de Jesús histórico, que en su práctica y predicación nos comunica la imagen correcta de Dios para una espiritualidad saludable coherente con su voluntad. Desde esta pers- 
pectiva Ellacuría (2002), nos dice que la espiritualidad cristiana es estar "llenos del Espíritu de Cristo [Jesús] y lo está de una manera viva y constatable, pues la fuerza y la vida de ese Espíritu invade toda su persona y su acción" (p.49).

Para Segundo Galilea (1985), la espiritualidad cristiana en tanto que mística, es la motivación y referencia explícita a Jesús, a su evangelio y la justicia de su Reino, no es simplemente la mística y motivación cualquiera, sino seguimiento de Jesús y su evangelio hecho experiencia.

Para Nolan (sf), la espiritualidad cristiana como vida espiritual es "la totalidad de una vida, en la medida en que es motivada y determinada por el Espíritu Santo, el Espíritu de Jesús” (p.2).

"La espiritualidad cristiana es la espiritualidad de Jesús, según su espíritu esa debe ser nuestra opción, la actitud de Jesús nuestras actitudes y la praxis nuestra praxis. Es una espiritualidad que tiene como centro a Cristo-Jesús histórico" (Casaldáliga, 1993). De igual manera, Gutiérrez (1975) conjuga espiritualidad y praxis de Jesús, pues la espiritualidad cristiana remite al dominio del espíritu del evangelio predicado por Jesús en su praxis, de ahí espiritualidad sea seguimiento a Jesús.
Imágenes de Dios nocivas para la espiritualidad cristiana

No toda imagen de Dios en la historia ha fundado espiritualidades saludables que crean relaciones fraternas y respeto por la vida. A lo largo de la historia del cristianismo se han venido construyendo espiritualidades que no corresponden a la imagen de Dios revelada por Jesús, son imágenes configuradas desde posiciones filosóficas o bien socio-políticas que fundan espiritualidades alienantes, dominadoras y destructoras de la vida humana.

Si bien las imágenes cumplen una función esencial, pues procuran precisar lo incognoscible, delimitar lo inagotable para que hombres y mujeres podamos situar nuestro espíritu y tengamos algo en que fijar nuestra imaginación y plegaria, el problema está cuando estas imágenes sustituyen a Dios, se convierten en imágenes idolátricas. (Robinson, 1962)

Fijémonos en algunas imágenes que han fundado en alguna medida espiritualidades que se han traducido en prácticas poco cristianas, pues el espíritu que las anima no siempre es considerado y discernido a partir de la práctica de Jesús. 


\section{La imagen del Dios todopoderoso.}

En nuestro fuero interno siempre se anida el deseo de tener un Dios que nos resuelva portentosamente todas las situaciones límites de nuestra vida, un Dios que elimine este mundo imperfecto de un tajo y nos haga uno perfecto; eliminación plena del mal, del sufrimiento y del dolor de modo definitivo y garantías seguras de la inmortalidad, como superación de la muerte.

La imagen del todopoderoso ha sido mal comprendida al ser relacionada con la figura del poder en su sentido de dominio, control e imposición. De ahí que esta imagen de Dios es tan peligrosa que con ella se puede justificar cualquier cosa que suceda en el mundo (Moltmann 1992). Este Dios toma distancia del mundo y se coloca en lo trascendente, lejos de las fragilidades y carencias en que viven las criaturas. Pues lo perfecto no puede compartir lo imperfecto, ni lo divino lo humano. "Un Dios todopoderoso - como diría el teólogo Bonhoeffer (citado por Gibillini, 1998) es como un Dios máquina al que se pone en movimiento para la aparente solución de problemas insolubles, el tapa-agujeros de muestras situaciones límites". Ese Dios nace del miedo a la muerte y el desamparo. $\mathrm{Su}$ función es disolver nuestros temores e incertidumbres, reduciéndonos al papel de hijos dóciles y obedientes.

¿Qué tipo de espiritualidades alimenta esta imagen de Dios todopoderoso? Al estar este Dios lejos y por encima del mundo se convierte en amo absoluto y opresor alienante. Luego se sigue una espiritualidad, cuya actitud fundamental consiste en servirlo y aplacarlo, en pedirle ayuda y favores, es una espiritualidad que se

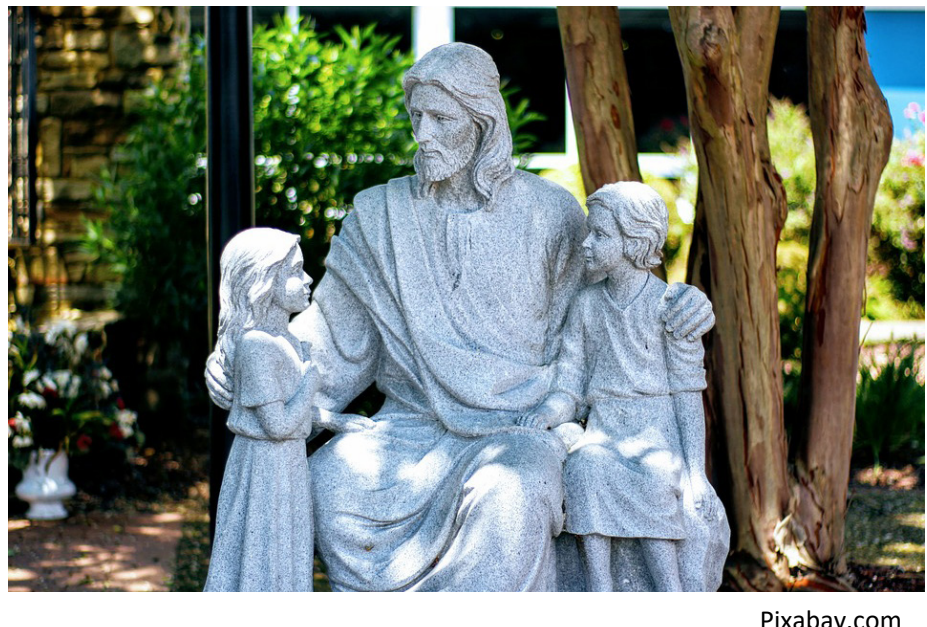

esfuerza por obtener "premio" y evitar su "castigo".

Los creyentes que se alimentan de esta imagen de Dios, por lo general desarrollan actitudes y prácticas impositivas, se colocan por encima de los demás, viven su cotidianidad en el eje del poder egoísta y dominador de cuantas esferas de relaciones de la vida les sea posible: religiosas, políticas sociales, éticas.

La imagen del Dios de los espacios sacrales versus espacios profanos.

Desde una visión dualista se ha configurado los espacios en una separación de un arriba y un abajo, calificados, uno, como sacral y otro, como profano; lo espiritual pertenece a lo de arriba, y lo carnal mundano y material a lo de abajo; Dios allá arriba y nosotros acá abajo, lo que pertenece a Dios y lo que no pertenece. (Shareenort, 2001)

La dificultad de esta imagen de Dios situada en un espacio sacral en oposición a lo profano consiste en que crea distancia, separación y oposición, en donde todo se juzga desde el 
criterio ético de lo bueno y lo malo. Esto tiene como resultado la creación de fronteras entre lo

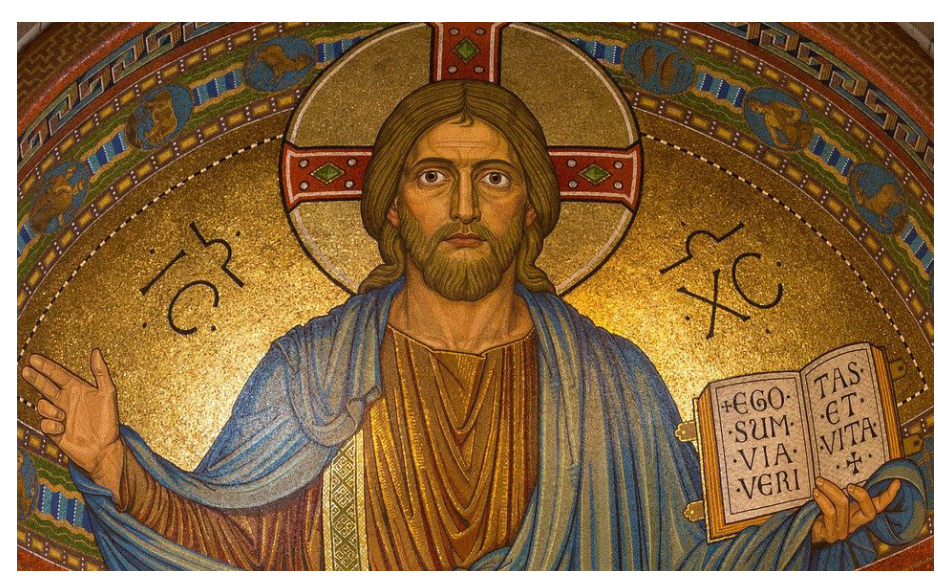

Pixabay.com

espiritual a lo material. Se juzgan o discriminan a las personas calificándolas de buenas o malas, espirituales o carnales-mundanas. De esa concepción deriva espontáneamente, una visión negativa de la vida y de la realidad. Dios no penetra más que lo espiritual, pues lo material está remitido al mal, por lo tanto, en oposición. (González Carvajal, 1996).

¿Qué espiritualidad se funda a partir de esta visión dualista? Si Dios está en la esfera de lo espiritual, nuestra espiritualidad habrá de procurar situarse en esa dimensión en separación de lo material, es una espiritualidad que huye, rechaza o juzga de poco el compromiso con vida concreta en sus dimensiones políticas, sociales, económicas o culturales.

Esta imagen de Dios alimenta espiritualidades de arriba, es decir, experiencias y vivencias con lo divino, expresado en éxtasis, manifestaciones prodigiosas en donde las personas sintonizan con un Dios en el más allá, tomando distancia de la dinámica del más acá histórico.
Produce una pérdida de sentido de la historia en su entramado sociopolítico-económico-cultural, en tanto que son espiritualidades movidas únicamente por las experiencias consideradas sobrenaturales.

\section{La imagen del Dios Señor Monárquico.}

Si bien las Sagradas Escrituras nos hablan de Dios como Señor, el Adonai o el Kyrios, lamentablemente en la historia, tal imagen fue comprendida nuevamente desde la figura del poder, Dios es Señor que se impone sobre todos y todo. Tal imagen concentra el poder del amo contrapuesto a la debilidad y sumisión del siervo. Es el Señor en su trono solitario, rodeado de súbditos. Al buen estilo de los imperios medievales, es Dios que espera ser servido, en donde todo creyente está frente a Él sólo para servirle en obediencia de súbdito que satisface la voluntad de su Señor.

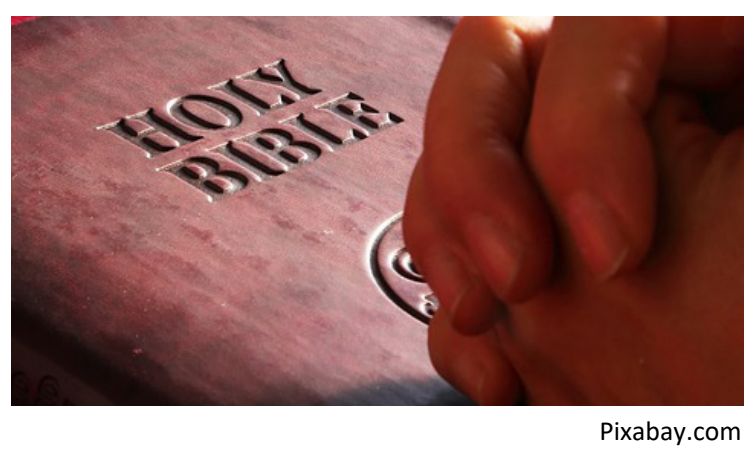

Si bien hemos de obedecer y servir al Señor, no así en esta imagen de Dios se aniquila la dignidad humana, la libertad convirtiéndonos en esclavos. En muchos imperios de la antigüedad el emperador o rey se presentó en un modelo significativo de Dios Señor y Monarca que está en el cielo. Si arriba hay un Señor monarca, abajo en la tierra habrá también un monarca emperador, rey sagrado como expresión de Dios (Pi- 
kaza, 2008). Un Dios único y Señor Monarca situado arriba en la trascendencia es imagen justificadora de los emperadores, monarcas o reyes aquí en la tierra. (Panikkar, 1998)

Una espiritualidad sustentada en esta imagen expresa solo obediencia y sumisión, satisfacción de la voluntad divina en la cual nosotros somos sus agentes de satisfacción. Las personas que sustentan su vida desde esa imagen se vuelven personas autoritarias, prepotentes, desarrollan actitudes de superioridad frente a los demás que son considerados inferiores, buscan que los sirvan y les rindan obediencia.

\section{La imagen del} Dios legalista.

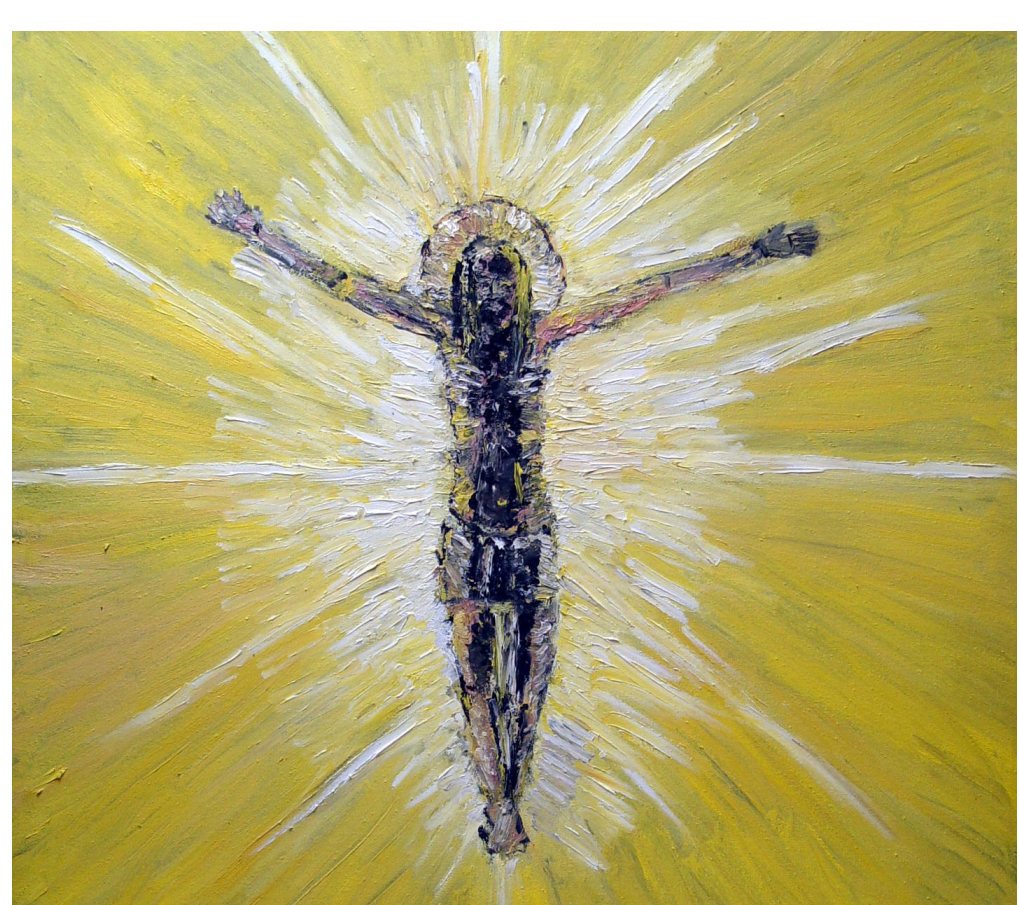

En esta imagen Dios dispone de modo absoluto lo que ha de Autor: Alfredo Caballero. Título: Resurrección
Esta imagen de Dios produce espiritualidades dogmáticas, cerradas e insensibles para con los que no cumplen con la ley o las normas establecidas por algún grupo o institución religiosa. Las personas que son movidas por esta comprensión de Dios se vuelven insensibles a los demás, duros frente al dolor y sufrimiento. Les satisface ser estrictos cumplidores de la doctrina, la norma o regla establecida en lo cual al creyente solo le queda ajustarse a esos parámetros, si quiere justificar su propia conducta. Pues a la espiritualidad legalista solo le interesa el acatamiento de la ley no la vida de las personas.

Jesús imagen de Dios y fuente de una recta espiritualidad

Jesús en su humanidad de manera concreta nos comunica ser cumplido y obedecido por todos. Es un dador de mandamientos dentro de la figura de ley, la cual deberá ser cumplida a cabalidad. Toda acción o práctica concreta en la vida cotidiana del creyente es juzgada y a su vez justificada, a partir de la obediencia u observancia de lo que Dios dispone. Esta imagen de Dios en la comprensión que Dios da leyes a cumplir se ha vinculado o relacionado con las instituciones socio-eclesiales que velan por el fiel cumplimento de lo que a criterio de ellas Dios ha mandado. al mismo Dios, de quien nos es imposible saber algo directamente, sino únicamente a través de una relación con Él. Con su decir y hacer Jesús nos da la manifestación plena e irrepetible de Dios. Hombres y mujeres somos imagen de Dios, no obstante, en Jesús se presenta de un modo único la imagen de Dios. Por su medio, Dios se ha hecho presente entre nosotros de un modo nuevo. No inicia con un discurso teórico sobre Dios o entorno a Dios, sino que en su práctica hace presente la realidad de Dios. 
(Aguirre Monasterio, 1985)

Jesús no es un hombre en quien se da una presencia de Dios distinta a él, como si estuviese poseído por Dios, sino que el mismo hombre Jesús es la presencia y revelación de Dios. En todas sus palabras y acciones tomamos conciencia de lo que Dios es para nosotros: amor y perdón, denuncia y exigencia, donación y presencia, elección y envío, compromiso y fuerza. (Caravias, 1985, pp.28-29)

Jesús es el modelo humano de búsqueda auténtica y verdadera de la imagen de Dios como posibilidad de configurar una espiritualidad saludable. "La espiritualidad cristiana es, por definición, la espiritualidad de Jesús, según su espíritu", nos dice Casaldáliga. (1993, p.6)

Jesús nos revela a Dios desde su práctica y para ello, se vale de ricas imágenes de profundas significaciones que marcan las nuevas relaciones con Dios, por ende, de una nueva espiritualidad.

Veamos algunas:

\section{La imagen del Dios paternal.}

En tiempo de Jesús la imagen de Dios se volvió muy oscura, la idea de lo santísimo había provocado un distanciamiento exagerado. Nadie se atrevía a pronunciar el nombre de Dios, pues él era el innombrable. "Jesús supera y clarifica definitivamente la imagen de Dios. Y nos acerca a Dios dirigiéndose a él como Abba. (Caravias, 1985).

Inaugura una nueva relación con Dios como
Padre intimizando así una relación profunda entre un hijo con su padre. Esta imagen paternal desplaza totalmente la actitud de siervos que se acercan al Señor monárquico todopoderoso, rompe las distancias y establece cercanías en un sentido profundo de familiaridad.

El teólogo Joaquín Jeremías (1974), sostiene que "En la invocación divina Abba se manifiesta el misterio supremo de la misión de Jesús, él tenía conciencia de estar autorizado para comunicar la revelación de DIOS, porque DIOS se le había dado a conocer como Padre. (p.81)

Para Jesús de Dios sólo podemos hablar en tanto que nos sintamos invitados hacia una nueva vida, de ahí que toma la imagen del Padre, para decirnos que Dios no está arriba ni está abajo, dentro o fuera de los hombres y mujeres sino con nosotros. (Pikaza, 1976)

Dios es Padre que asume una actitud perdonadora, para Jesús ese es el punto fundamental y de partida de su oración del Padre Nuestro. Perdón que deviene en reconciliación con Dios y con nuestro prójimo. Jesús mismo interpreta el perdón de Dios como expresión de su bondad paternal. Dios es padre bueno que reparte sol y bendición a todos, Padre que ofrece perdón
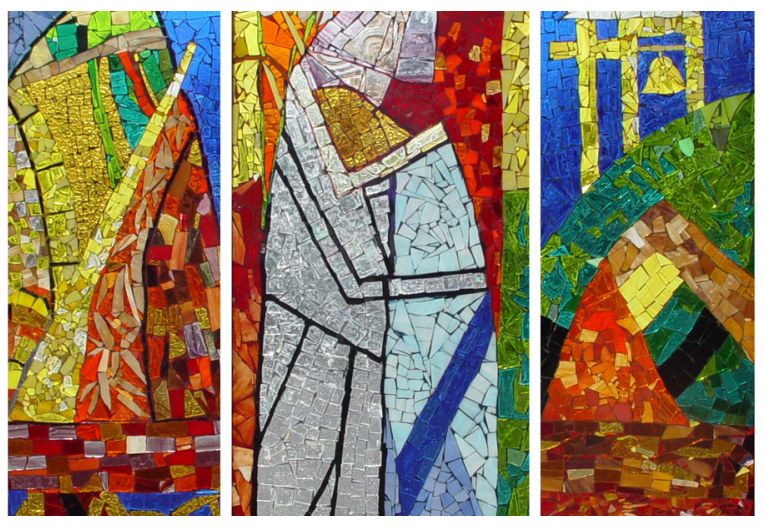

Autor: Rossi López. Título: El Hijo Pródigo 
para los buenos y los malos (Pikaza, 1976). En este sentido la nueva imagen de Dios como Padre que propone Jesús, nos lleva a crear otra relación con Dios, ya no el juez, el Señor dominador que marca los destinos arbitrariamente sino Dios cercano, familiar viniéndonos a constituir en hijos e hijas de Dios.

\section{La Imagen de Dios amoroso.}

Jesús desde su propia experiencia de vida saborea la cercanía de ese amor de Dios y lo co-
Convirtiéndose así, en el portador del amor y perdón de Dios a todos los hombres.

Jesús es la presencia amorosa y perdonadora de Dios en medio de nosotros. En su obrar podemos experimentar la concreta cercanía de Dios; por su medio el amor radical de Dios se modeló humanamente" (Caravia 1985). Jesús es el amor de Dios encarnado en su humanidad. No es respuesta al amor recibido, es amor que toma la iniciativa y crea el amor por su propia insistencia, amor a los más desprotegidos, amor

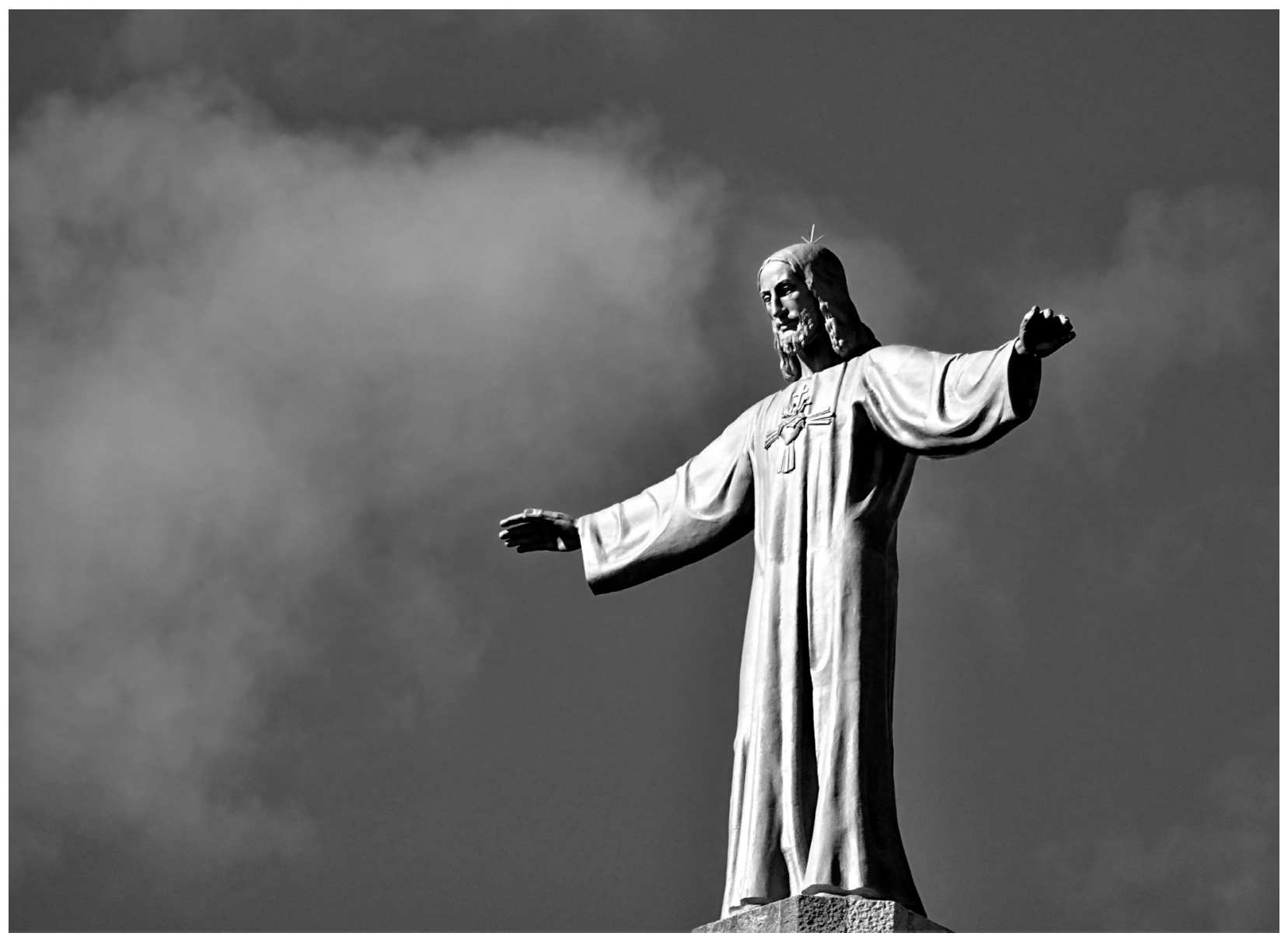

Pixabay.com

munica con toda sencillez. Lo vive y lo da a conocer en una actitud concreta. Fue un permanecer en el amor del Padre (Jn 15,10). De quien recibe una participación plena de su vida, de su conocimiento y de sus obras (Jn 1,18; 5,19-20). a los enemigos que supone perdón. (Comblin, 1977)

El único poder de Dios es el amor desarmado.

Dios no tiene otro poder que el de amar. Una 
espiritualidad que se funda en la actitud amorosa de Dios anula en su totalidad el egoísmo, el individualismo, la prepotencia, y la soberbia, más bien crea y abre espacios amorosos de una relación de hermanos y hermanas en Dios.

El Dios de Jesús no es insensible ante los dolores humanos. Él es constitutivamente en su realidad misericordioso y compasivo. Dios, por amor, participa del sufrimiento humano, sin perder nada por ello de su dignidad divina. Todo lo contrario. El poder de Dios no es el Dios que aplasta sino el que traduce su poder en su libre exposición al sufrimiento y el dolor de los demás, todo por amor y misericordia. Así Jesús en su práctica reveladora de Dios pone en primer lugar, la vida de las personas, la curación de los enfermos, la reconciliación social, la acogida amistosa al pecador y el perdón sanador. (Pagola, 2011)

Jesús capta y vive la realidad de Dios como bondad y compasión. Lo que define a Dios no es el poder ni la sabiduría, sino sus entrañas maternales de Padre. La compasión es el modo de ser de Dios, su manera de mirar el mundo y de reaccionar ante sus criaturas. El Padre lo vive todo desde la compasión. Esta es la experiencia de Dios que comunica Jesús en sus parábolas más conmovedoras y que le impulsa a proclamar un nuevo principio de actuación. (Pagola, 2011 p.4)

\section{Dios en apertura y servicio}

Jesús nos comunica una imagen de Dios que se abre a todos. Jesús es Dios para los demás. En su experiencia con Dios Padre toma conciencia clara que vivir es vivir para los otros, servir a los otros "yo no he venido para ser servido sino para servir", nos dice Jesús.

Por eso no se niega a nadie, sobre todo a los estigmatizados, excluidos o marginados en la sociedad de su tiempo. Recibe y escucha a la gente, muchas de ellas tenidas como sospechosas o prohibidas, sean mujeres o niños, prostitutas, recaudadores de impuestos, enfermos, samaritanos, gente piadosa, ricos o pobres. A todos ellos se acerca aun en contra de las profundas diferencias discriminadoras de la época. La espiritualidad de Jesús es abierta, acogedora de todos y todas a la comunión del Padre, las fronteras se rompen y Dios está en los mismos espacios que habitamos.

Vivir una verdadera espiritualidad fundada en el Dios de Jesús

¿Qué significa vivir una espiritualidad desde la imagen de Dios comunicada por Jesús?

La comunión con Dios crea una espiritualidad que logra su identidad en la filiación al Padre, donde nuestra apertura se traduce como una relación filial entre Dios y todos nosotros, se crea comunión no sólo con Dios, sino entre nosotros convirtiéndonos en comunidades fraternas de hijos e hijas de Dios que caminamos juntos en el camino de nuestra realización humana. Esta espiritualidad anula radicalmente cualquier relación de poder subyugante, visibiliza la vida y la pone en el centro de todo nuestro pensar, sentir y actuar.

Espiritualidad que nos sensibiliza a vivir atentos, no hacia nosotros mismos de forma egoísta, sino atentos a los demás que sufren, que son 
marginados o excluidos despierta en nosotros la solidaridad fraterna, el compromiso liberador para con los excluidos, discriminados o marginados por el sistema social. (Pagola, 2011)

\section{Espiritualidad que crea diaconía.}

El Dios que viene para servir y no ser servido anula toda imagen de Dios Señorial. La espiritualidad del que cree en este Dios diaconal pondrá en juego la voluntad de darse a los demás, el poder ya no será de dominio, sino del poder que sirve pro de la realización de los unos a los otros.

Espiritualidades generadoras de la paz (shalom).

El Dios que decide libremente asumir nuestra humanidad, asume también nuestra historia con todas sus debilidades y fortalezas. Derrumbadas las fronteras que dividen lo espiritual y material deviene relaciones de Dios que penetran toda la vida humana y planetaria. Si Dios es el que nos impulsa a vivir la vida significa una vida dentro de una problemática, desafíos, espacios personales y naturales, actitudes, actos, a través de ciertas mediaciones psicológicas, sociológicas, políticas, pastorales, evangélica con vistas a la opción fundamental, que dará sentido, fuerza, alegría y victoria a nuestra vida, bienestar y tranquilidad al vivir. Así la espiritualidad saludable construye un bienestar total de la vida, es el shalom de Dios, la armonía con todo y todos.

\section{Conclusión}

La espiritualidad no responde a un estado de- finitivo de perfección sino en un caminar en búsqueda. Lo cual nos desafía en primer lugar a estar en continua apertura y voluntad de transformar nuestra prácticas cristianas, es en la vida diaria-cotidianidad donde vamos configurando la espiritualidad, no como tarea acabada sino como un caminar continuo donde Dios en Jesús y a través de su Espíritu presente en nosotros que nos da su impulso, para vivir, soñar, reír, compartir, amar, servir; y en Segundo lugar, una espiritualidad que sea capaz de integrar la realidad de Dios en sus actos amorosos y salvíficos en nuestra realidad histórica en donde podemos construir espiritualidades maduras y responsables.

\section{Referencias}

- Aguirre Monasterio, Rafael. (1985). El Dios de Jesús. Madrid: Santa María

- Andrés Torres Queiruga. (1996). Un Dios para hoy. XXVII Asamblea Mundial de Pax Romana, Dobogókö Hungría.

- Arocena, José (2014) Buscando a Dios en el siglo XXI.Montevideo, Uruguay: Trilce.

- Birgit Schareenort. (2001). Más allá de lo sagrado y lo profano: experiencia y lenguaje religioso. Bogotá: Universidad Philadelphia. 37. pp. 95-112-

- Boff, Leonardo. (2012). Dimensión de lo profundo: el espíritu y la espiritualidad. Recuperado: https://leonardoboff.wordpress. com/2012/08/28/dimension-de-lo-profundo-el-espiritu-y-la-espiritualidad/

- Caravias, José Luis. (1985). El Dios de Je- 
sús. Quito: Edicay.

- Casaldáliga, Pedro. (1993) Espiritualidad de la liberación. Santander: Sal Terrae.

- Comblin, José. (1977). Jesús de Nazaret: meditación sobre la $\mathrm{v}$ ida y acción humana de Jesús. Santander: Sal Terrae.

- Zubiri, X. (1989). Estructura dinámica de la realidad. Madrid: Alianza.

- Dussel, Enrique. (1975). El humanismo helénico. Buenos Aires: Eudeba.

- Ellacuría, Ignacio. (2001). Escritos teológicos. Tomo IV.San Salvador: UCA.

- Galilea, Segundo (1985). El camino de la espiritualidad. Bogotá: Paulinas.

- González Carvajal, Luis. (1996). Esta es nuestra fe: teología para universitario. Bilbao: Sal Terrae.

- Gutiérrez, Gustavo (1975) Teología de liberación: Perspectivas. Salamanca: Sígueme.

- Ignacio Núñez de castro (2010) ciencias y nuestras imágenes de dios. Recuperado de http://servicioskoinonia.org/relat/401.htm

- Jeremías, Joachim. (1974). Teología del Nuevo Testamento. Salamanca: Sígueme.

- Moltmann, Jurgen. (1989).La justicia crea futuro. Santander: SalTerrae.

- Nolan, Albert (sf).espiritualidad bíblica espiritualidad de la justicia y el amor. recuperado de https://missaototal.files.wordpress. com/2010/05/espiritualidad-de-la-justicia-y-el-amor.pdf

- Nuñez de Castro, Ignacio.(2010). Las ciencias y nuestras imágenes de Dios. Recuperado de http://servicioskoinonia.org/relat/401. htm

- Pagola, José Antoni. (2011). Espiritualidades centrada en Jesús, Encrucillada (s.e)

- Panikkar, Raimon (1998). La Trinidad: una experiencia primordial. (sl): Siruela.

- Pikaza, Xavier (1976) Los orígenes de Jesús: ensayo de cristología bíblica. Salamanca: sígueme.

- Pikaza, Xavier (2009). Gritos y esperanzas de nuestro mundo una mirada desde el evangelio. CONFER.

- Pikaza, Xavier. (2008).Dios es comunión, no monarquía sagrada (contra los reyes cristianos). Recuperado: https://www.religiondigital.org/el_blog_de_x-_pikaza/ Dios-comunion-mon las arquia-sagrada-cristianos_7_918578160.htm

- Robinson, John A.T. (1962). Sincero para con Dios.sl se.

- Rosini, Gibellini. (1998).Teología del siglo XX. Sal Térrea, Santander.

- Silva Gotay, Samuel. (1983). Pensamiento cristiano revolucionario en América Latina y el Caribe. Salamanca: Sígueme. 